\title{
Death of a Salesman, When Tragedy Meets the Modern Man
}

\author{
Marsela Turku \\ Aleksandër Moisiu University, Durrës, Albania
}

\begin{abstract}
The most persistent criticism about the play Death of a Salesman (1949) concerns the issue of genre and its constituents: Is it a tragedy?! If yes, to what extend is it a tragedy? Miller himself considered the play to be the tragedy of the common man, as he presents his idea on tragedy as a genre and his idea of the tragic hero in his essay “Tragedy and the Common Man” (1942), but for a group of critics it is not a tragedy but to others and to the author, it is the tragedy of the man who tries to survive in the modern world by using archaic weapons. This paper briefly revisits the Aristotelian tragedy concept and modern theories, and stands on what are tragedy and a tragic hero. It aims at reading Death of a Salesman as a meeting point between (ancient) concept of tragedy with modern man and his way of seeing life, and briefly examines and explores the continuing disagreements among academics and by what criteria this play is a tragedy.
\end{abstract}

Keywords: tragedy, modern man, Aristotle, tragic hero

\section{Introduction-What Is Tragedy?}

Tragedy is an achievement peculiarly in Greek. It was the first to perceive and gave it the splendour and the highness that we all know, throw the tragedies of Aeschylus, Sophocles, and Euripides. The philosophy of the human nature is implicit in the human speech, consequently in these tragedies, the result of inquiries done to the human nature which is bound up with evil and dark "gods", tries to present the human being as it really is. The Greek tragedies were characterized by a sincere need to perceive the beauty the reality offered through clarity, calmness, and serenity. Their positive attitude towards the gloomy aspects of life somehow creates a magic atmosphere and illumining visions where beauty is transmitted only through truth and vice versa truth implies beauty.

A tragedy shows us pain and gives us pleasure thereby. The greater the suffering depicted, the more terrible the events, the more intense our pleasure. The most monstrous and appealing deeds life can show are those the tragedian chooses, and by the spectacle he thus offers us, we are moved to a very passion of enjoyment. (Hamilton, 1930, p. 229)

The reader is unable to explain this tragic pleasure. A number of scholars through the centuries have considered this conflicting feeling as the substructure of tragedy and fundamental element in the continuing of the genre. Just to mention, Aristotle called it "pity and awe", "and a sense of emotions purified thereby”. For Hegel, it is the reconciliation between life's temporary dissonances resolved into eternal harmony. For Schopenhauer, it is the acceptance in the fulfilment of the will, "Thy will be done". For Nietzsche, it is the "the reaffirmation of the will to live in the face of death”, “and the joy of its inexhaustibility when so reaffirmed” (Hamilton, 1930, p. 230).

Marsela Turku, Ph.D. candidate, Department of Foreign Languages, Aleksandër Moisiu University. 
The play Death of a Salesman (1949) has raised a lot of debates and criticism through the years for its themes, whether or not it is a tragedy, the place it occupies in the American Drama, its "pathos" and impurities, for the downfall of its hero, etc., but what has been one of the most discussed issues of the play is its genre, some critics claim that it is a tragedy, others classify it as a "social drama", while others consider it neither as a tragedy, nor as a social drama, but a pure Broadway production. This paper aims at reading Death of a Salesman as a meeting point between (ancient) concept of tragedy with the modern man and his way of seeing life. Miller himself, dared to explain and explore the reason and his personal viewpoint on tragedy of "Tragedy and the Common Man” (1949), although a number of scholars have criticized Miller and his ideas on tragedy. However, in the character of Willy Loman, Miller transcends Aristotle's notions of "the tragic hero" and expands on them with his own ideas of what creates a truly moving character and an emotionally rich play who has been able to surpass cultural borders and generations.

\section{Aristotle's Poetics vs. Miller's “Tragedy and the Common Man”}

"In this age few tragedies are written. [...] For one reason or another, we are often held to be below tragedy, or tragedy above us. The inevitable conclusion is, of course, that the tragic mode is archaic, fit only for the very highly placed, the kings or the kingly, and where this admission is not made in so many words it is most often implied"”. (Miller, 1949, pp. 3-7)

Miller begins his essay “Tragedy and the Common Man” by asserting that there are no more tragedies and the modern man could not fit the archaic tragic mode, although he strongly believes that "the common man is as apt a subject for tragedy in its highest sense as kings were” (Miller, 1949, p. 3) by referring to modern psychiatry which bases its analysis upon classic formulations, such as Oedipus and Orestes complexes. Miller also claims that the tragic feeling is evoked when we are presented with a character that is even ready to give up his own life to secure personal dignity or his rightful position in the society. The main character in the Death of a Salesman, Willy, is a product of Miller's ideas and embodies that the common man can be a tragic hero and he must be the modern tragic hero, the one who fits to the modern tragic mode. Thomas E. Porter claimed that:

Willy's status in society, his family background is typical; even more of a type is Willy's identity as a Salesman. He is a product of a producer-consumer society in which the go-between is a pivotal figure. Society has labeled him, and Willy has accepted the label; society has offered Willy a set of values and an objective, and Willy has committed themselves to those values and that objective [...] He has been shaped by a society that believed steadily and optimistically in the myth of success, and he has become the agent and the representative of that society. (Martine, 1976, p. 29)

If we revisit chapter six of the Poetics, Aristotle presents the core of his poetic doctrine and aesthetic theory. He defines the purpose and essence of tragedy as:

The imitation of an action which is serious, complete in itself and of a certain magnitude; in language which is embellished with artistic ornaments; in a dramatic not a narrative form; with incidents which arouse pity and fear and accomplishing the catharsis of these emotions ${ }^{2}$.

\footnotetext{
1 Arthur Miller, “Tragedy and the Common Man” from The Theater Essays of Arthur Miller (Viking Press, 1978, pp. 3-7). Copyright 1949, Copyright 0 renewed 1977 by Arthur Miller. Reprinted by permission of Viking Penguin, Inc.. Retrieved from http://theliterarylink.com/miller1.html.

${ }_{2}$ Cited from the Project Gutenberg ebook of Poetics, by Aristotle. Retrieved from http://www.gutenberg.org/files/1974/1974-h/1974-h.htm.
} 
He qualifies the six component parts of a tragedy: plot, characters, diction, thought, spectacle, and choral music, and emphasizes the unity which these component parts must preserve to ensure the unity of the organic whole. According to Aristotle, another important element is the plot "the soul of a tragedy". The plot is “... the first and most important thing in tragedy" ${ }^{3}$ and it should have a beginning, middle, and end, that all parts follow each other in concise fashion, the parts should not be “... 'episodic' in which the episodes or acts succeed one another without probable or necessary sequence", thus "we must confine ourselves to the actions on the stage" (Perry, 2012). Miller's play fits this entire principle on the complex plan, simply explained that we have a beginning where the hero is a successful salesman with a "happy” family, a middle where our hero loses his job and goes through the unsurprising struggles and realities of being a salesman, his family discovers that Willy is not the perfect father but has his character "flaw", and a classic tragic end wherein our hero dies. The sequence of Willy Loman's life is indeed "probable” and all parts are necessary to the wholeness of the play.

Aristotle defines the hero as "a man not outstandingly good and just whose misfortune is brought about not by vice or depravity but by some error of judgment $\left.t^{5}[\ldots]\right]^{\prime 6}$. In this definition, the Aristotelian ethical principle of character and choice becomes evident — the character of a man may be adjudged by the choices he makes and to illustrate his poetic doctrine Aristotle cites a number of Greek tragedies as well as the Iliad and the Odyssey. In Sophocles' Oedipus the King (420 BC.), he finds the greatest number of illustrative virtues and the highest degree of dramatic competence.

Willy Loman displays a number of qualities of which Aristotle would consider to be that of a tragic hero, he encompasses harmatia which takes form in his foolish pride, and dreams he could not accomplish. Throughout the play it is pointed out to the reader that Willy's foolish pride has led to the failure of achieving his dream as well as financial imbalance. Pride leads Willy to shield himself in delusion rejecting any blame that could fall upon him and constantly blaming others for all that goes wrong in his life. By blaming others Willy is never able to see his errors and correct them... (Jozzoms, 2012)

Willy, also can be seen to fit with the idea of Peripeteia ${ }^{7} .$. His fortunes reversed as he starts the play in a position in which he still has a job, has some respect from his family and is hoping to see his sons start a business together and see them finally make a success of themselves. His eventual death is also tragic, in the fact, he, the salesman, sells his life in order to make his life worth living. He feels that in death he is worth more than in life, and so sacrifices himself... (Jozzoms, 2012)

Does Willy have Anagnorisis? Unfortunately, up to the end, he is blinded by his pride and the archaic attitude to the modern business world, and by constantly mistaking material benefits for spiritual benefits. At the end of the play, it is his son Biff who experiences the moment of enlightenment and understands the miscalculation of his father and promises that his dreams would not go in vain.

\footnotetext{
3 Cited from the Project Gutenberg ebook of Poetics, by Aristotle. Retrieved from http://www.gutenberg.org/files/1974/1974-h/1974-h.htm.

4 Cited from the Project Gutenberg ebook of Poetics, by Aristotle. Retrieved from http://www.gutenberg.org/files/1974/1974-h/1974-h.htm.

${ }_{6}^{5}$ Italics are the author's.

6 Cited from the Project Gutenberg ebook of Poetics, by Aristotle. Retrieved from http://www.gutenberg.org/files/1974/1974-h/1974-h.htm.

7 According to Aristotle, the tragedy is centered on the heroes "fall from his initial high status, in a reversal of fortune". Aristotle named this term Peripeteia. This fall from grace would be brought about by the hero's fatal flaw. This fatal flaw led to the series of events in which the hero's demise would occur called Hamartia. The hero of the play eventually suffers a moment of insight, where he "realises what he has done and gains a new perspective on the truths of human existence". This moment of enlightenment is called Anagnorisis.
} 
The key idea to Aristotelian tragedy is its tragic hero: "man who enjoys prosperity and a high reputation". However, Willy does not belong to high social rank, nor is he of noble origin, thus, according to Aristotle's views on tragedy, Willy does not have a high position to fall in, neither a fortune to be reversed, and for these reasons he is not qualified to be a hero of tragedy. Miller states in his essay that the common man can be subject to tragedy and through Willy's character he gives life to a new tragic hero that of the common man who faces struggles most might encounter. The "common man" and situations such as those depicted in Death of a Salesman are those which the common man can relate to a large number of people and is more effective in arousing pity in the audience, as they identify him and his struggles with themselves. Willy, like many Americans, had his own interpretation of what the "American dream" is and how to fulfil it; he tries to accomplish it, however, fails miserably, as many others had done before him, and others are about to do after him. As Miller (1949) stated in his essay:

The quality in such plays that does shake us, however, derives from the underlying fear of being displaced, the disaster inherent in being torn away from our chosen image of what or who we are in this world. Among us today this fear is as strong, and perhaps stronger, than it ever was. In fact, it is the common man who knows this fear best. (pp. 3-7)

\section{The Modern Tragic Hero}

It is obvious that "the idea on tragedy" has escaped its classical generic determination in Aristotle’s Poetics and had expanded into the role of an intellectual concept of astonishing amplitude and the culmination came in Nietzsche's Birth of Tragedy (1872). He claimed that "tragedy arose as artistic energies which burst forth from nature herself, without the meditation of the human artists" (Nietzsche, 1993, p. 38). For Nietzsche, the incarnation of the tragic is the mythic figure of Dionysus who personifies the eternal and original artistic power that first calls the whole world of phenomena into existence...” (Nietzsche, 1993, p. 143). Nietzsche's work presents the tragedy as a battle of creative energy against the world of reason and the human beings that inhibit these tragedies are left alone with a feeling of alienation and despair in facing death.

In contrary to Nietzsche's attitude, Miguel de Unamuno, in his Tragic Sense of Life (1913) did not refer to tragedy as a literary genre, but rather he sees it as a complexity of things which springs from the conflict between human nature and social reality. He believes that changes in science and technology are reflected into human reasoning, and in addition these developments manifest themselves in consciousness. He claims that consciousness depends on memory and memory is bridging gap between the past and the present, between the present and the future, between what we have lost and what we actually have; and these memories do not necessarily have to be happy or joyful ones: "No one has ever proved that man must necessarily be joyful by nature" (de Unamuno, 1913, p. 22).

Although tragedies throughout history have usually kept within the boundaries of what are deemed conventional and the parameter set out by Aristotle, parameters of tragedy until the Elizabethan times, and Shakespeare's attempt at adopting the genre to the literary period and the audience's interest by breaking some of them. Shakespeare's Hamlet is a good example of how playwrights have attempted to break these constraints. Hamlet is not the nobility mentioned in the poetics, as he is not a King, or a Queen, but a Prince, and he is also seen as not having the fatal flaw that is necessary of a tragic hero for his tragic doom. His irresolution is generally seen as being the missing flaw; however, the author strongly believes that it is not a flaw but a device, as: 
Shakespeare is trying to make Hamlet a morally reflective and very insightful character, showing his attempt at morphing the genre of tragedy to be more relevant to his era. This can be seen as in his time, the audience was more interested in seeing moral conflict on the stage then a simple fall from grace. However, Shakespeare still embraced the majority of the poetics, and there is still a moment of insight and a purging of the audiences emotions presented in the play. ${ }^{8}$ (Miller, 1949)

Others have tried to reinvent the genre after Shakespeare, but have not gone too far from the conventional form.

Steinberg (1969) believed that the modern drama of the 20th century should expose the common man and compare it to the tragic figures of the past. He also supported Miller's idea that the classical tragic archetypes should be brought in a modern context: "As the twentieth century approached, various sources were making for realism in drama with its emphasis on people and situations drawn from ordinary life” (Steinberg, 1969, p. 81), because realism breeds proximity and the closer to the real world the more will the public sympathize with the characters and affect them, as it is described in the Aristotelian sense, by invoking both "panic" and "empathy" (in original "phobos" and "eleos”) when characters are brought into utter despair.

To fit with the modern frame of thought, and to make it more relevant to the modern audience, Miller uses more modern approaches such as the ideas of alienation, modernization, and themes such as capitalism, diffusing dreams with reality, displacing a human being from his chosen image, the conflict between human nature and social reality, etc.. Miller (1949) stated that:

Our lack of tragedy may be partially accounted for by the turn which modem literature has taken toward the purely psychiatric view of life, or the purely sociological. If all our miseries, our indignities, are born and bred within our minds, then all action, let alone the heroic action, is obviously impossible ${ }^{9}$.

Arthur Miller's Death of a Salesman dares to break the archaic Aristotelian pattern, pushing the boundaries of what we considered to be the norm, changing from what has always been the "ideals" of tragedy and to some extend, it has been claimed as the critical reinvention of the tragic genre mainly through his hero. Furthermore, de Unamuno (1913) strongly believed that tragedy and tragic are inseparable comrades to the human being and to his identity: "Man, because he is man, because he possesses consciousness, is already, in comparison to the jackass or the crab, a sick animal. Consciousness is a disease” (p. 22), thus, for de Unamuno, the consciousness possesses no time reference, it is deeply rooted in men's character and that is why tragedy and tragic are within the human being, disregarding his social rank, consequently the failure of this common man is the tragedy of any man.

\section{Conclusions}

The majority of the critics focus mainly on the fact that Willy is not a man who enjoys prosperity and a high reputation, he is not a King and his actions do not affect a large number of people and he does not have the potential to achieve greatness, and according to Aristotle, the tragedy should be centred on the heroes fall from his initial high status, in a reversal of fortune. However, we should not forget the fact that in the 20th century, the influence of the Kings and their alike is dim, shapeless, and diffuse. Their fall may and does not provoke the same reaction, they do not have the same potential to achieve greatness as they used to have in the Aristotle's time, thus

\footnotetext{
${ }^{8}$ Retrieved from http://lozzoms.hubpages.com/hub/Tragedy-and-the-common-man.

${ }^{9}$ Retrieved from http://www.nytimes.com/books/00/11/12/specials/miller-common.html.
} 
catharsis is harder to attain. Miller addresses his tragedy to the 20th century people who struggle with alienation, modernisation, and the capital societies; he addresses to those people who, at the end of the month, have to pay the mortgage, the bills, to teach their children the right values to successfully deal and survive in the capital society, to secure economic stability to his wife and children and of course "happiness" to them, and the realization of the American Dream to his neighbours' eyes and society. How many people do the same everyday, every year, and every generation?! The answer is a lot of us, the majority of us, not only in the USA but everywhere; we fight, struggle, and if we are lucky, we may survive; and if we are not we have the same tragic end as Willy. "It is time, I think, that we who are without kings took up this bright thread of our history and followed it to the only place it can possibly lead in our time- the heart and spirit of the average man" (Miller, 1949, pp. 3-7), because he is the only one who can deeply affect our consciences.

\section{References}

Aristotle. (2008). The poetics of Aristotle. (S. H. Butcher Trans.). Retrieved from http://www.gutenberg.org/catalog/world/readfile?fk_files=3274703

de Unamuno, M. (1913). Tragic sense of life. New York: Dover Publications, Inc..

de Unamuno, M. (1972). The tragic sense of life in Men and Nations. (A. Kerrigan Trans.). Princeton: Princeton University Press.

Hamilton, E. (1930). The Greek way. New York: W. W. Norton \& Company. Inc..

Jozzoms. (2012, March 12). "Tragedy in Death of a Salesman" In HubPages. Retrieved from http://lozzoms.hubpages.com/hub/Tragedy-in-death-of-a-salesman

Martine, J. J. (1976). Critical essays on Arthur Miller. Bosston: G. K. Hall \& Co..

Miller, A. (1949). Death of a Salesman. New York: Viking Press Inc..

Miller, A. (1949, February 27). Tragedy the common man. New York Times. Retrieved from http://www.nytimes.com/books/00/11/12/specials/miller-common.html

Miller, A. (1978). Tragedy and the common man. The theater essays of Arthur Miller (pp. 3-7). New York: Viking Press. Retrieved from http://theliterarylink.com/miller1.html

Morgan, F. (1979). Review of Death of a Salesman. In J. J. Martine (Ed.), Critical essays on Arthur Miller. Boston: G. K. Hall \& Co..

Nietzsche, F. (1992). Basic writings of Nietzsche. W. Kaufman (Trans. \& Ed.). New York: Random House Inc..

Nietzsche, F. (1993). The birth of tragedy. S. Whiteside (Trans \& Ed.). London: Penguin Edition.

Perry, J. (2012, October). The extents to which The Death of a Salesman is an Aristotelian tragedy. Retrieved from http://www.joelperry.com/2007/02/the_extents_to_which_the_death.html

Porter, E. T. (1979). Acres of diamonds: Death of a Salesman. In J. J. Martine (Ed.), Critical essays on Arthur Miller (pp. 24-43). Boston: G. K. Hall \& Co..

Shattuck, R. (1996). Forbidden knowledge: From Prometheus to pornography. New York: St. Martin’s Press.

Steinberg, M. W. (1969). Arthur Miller and the idea of tragedy. In R. W. Corrigan (Ed.), Arthur Miller: A collection of critical essays (pp. 81-94). Englewood Cliffs: Prentice-Hall Inc..

Turku, M. (2011). The tragedy and the human being in Arthur Miller's play Death of a Salesman. Sarajevo: Burch University. Retrieved from: http://eprints.ibu.edu.ba/120/ 